\title{
Effect of flow rates of gases flowing through a coal bed during coal heating and cooling on concentrations of gases emitted and fire hazard assessment
}

\author{
Marek Więckowski ${ }^{1}$ Natalia Howaniec $^{2}$ (D) Adam Smoliński $^{3}$ (i)
}

Received: 12 August 2019/Revised: 26 September 2019/Accepted: 19 November 2019/Published online: 29 November 2019

(C) The Author(s) 2019

\begin{abstract}
The flow velocity of gases in gobs directly influences the kinetics and intensity of gaseous components release during heating and cooling of coal. The assessment of fire hazard is performed on the basis of concentrations of particular gases in a mine air. These concentrations differ in coal heating and cooling phase which was proven in the study. This paper presented the results of the experimental study on temperature distribution in a simulated coal bed in heating $\left(50-250{ }^{\circ} \mathrm{C}\right)$ and cooling $\left(250-35^{\circ} \mathrm{C}\right)$ phases as well as its correlation to variations in concentration of gases released in these phases and flow rates of gases flowing through the coal bed. The research was performed on twenty-two samples of bituminous coals acquired from various coal beds of Polish coal mines. Considerable differences were observed between heating and cooling phases in terms of the concentrations of gases taken into account in calculations of self-combustion index. In the heating phase temperature increase resulted in the decrease of concentrations ratios of ethane, ethylene, propane, propylene and acetylene, while in the cooling phase these ratios increased systemically. The effect of air (in heating phase) and nitrogen (in cooling phase) flow rate on the self-ignition index $\mathrm{CO} / \mathrm{CO}_{2}$ was also determined.
\end{abstract}

Keywords Coal $\cdot$ Self-heating $\cdot$ Fire hazard $\cdot$ Flow rate

\section{Introduction}

The application of the rules of fire prevention and combating underground fires contributed to decreasing fire hazard risks in coal mining. Technical advancement and the development of scientific research enables further progress in terms of the better understanding of coal self heating and cooling processes. The mine air constitutes a solution of atmospheric air and the gases which are emitted in the coal mine. Gaseous products generated as a result of

Natalia Howaniec

n.howaniec@gig.eu

1 Department of Mining Aerology, Central Mining Institute, Plac Gwarków 1, 40-166 Katowice, Poland

2 Department of Energy Saving and Air Protection, Central Mining Institute, Plac Gwarków 1, 40-166 Katowice, Poland

3 Central Mining Institute, Plac Gwarków 1, 40-166 Katowice, Poland oxidation reaction play an important role in the occurrence of underground fire. Because of incomplete combustion, fire gases contain toxic ingredients such as carbon monoxide, hydrogen sulphide, hydrogen cyanide, sulphur dioxide, as well as the following flammable gases: methane, hydrogen, and hydrocarbons (Dai 2007; Beamish and Arisoy 2008; Brady et al. 2009; Adamus et al. 2011). The development of the process of coal self-ignition is possible when three conditions are met, namely the presence of a sufficient amount of crushed coal, air ingress to the location where coal has been amassed and the possibility of heat accumulation (Beamish et al. 2001; Wang et al. 2003; Zubicek and Adamus 2013; Xia et al. 2014; Arisoy and Beamish 2015; Deng et al. 2015). The first one is associated with natural geological conditions while the remaining two depend on the methods of ventilation, which means that the application of an appropriate ventilation method may decrease the risk of fire incidents. According to mining regulations, fresh air in mine gobs where people 
stay should contain at least $19 \%$ of oxygen (volumetrically) and should not exceed $1 \%$ of carbon dioxide. The methane content should not exceed $0.5 \%$ while the content of harmful carbon monoxide should not exceed $0.0025 \%$. The research concerning coal self-ignition processes has been carried out for decades. The pyrite theory discussing spontaneous coal self-heating due to the interaction of oxygen, water and pyrite content in coal was formulated as early as the $17^{\text {th }}$ century. In addition, numerous methods for determining coal tendency to self-ignition have been developed. Most of the methods are based on determining the temperature of self-ignition and establishing the velocity of coal oxidation. The research on low-temperature coal oxidation in the range of $30-250{ }^{\circ} \mathrm{C}$ was conducted by Kaji et al. (1985). In turn, Wang et al. (1999) performed a theoretical analysis of low-temperature coal oxidation using a pore model resembling tree structures. Ren et al. (1999) presented the results of research on adiabatic oxidation of coal dusts and their tendency to selfignition. Nugroho (2000) investigated the impact of particle size on coal self-heating process. Beamish (2005) introduced the R70 coal self-heating rate. Taraba and Pavelec (2014) presented results of a study on flow calorimetry applied to the assessment of coal self-heating using the value of oxidation heat. Feng and Adamus (2014) determined the factors affecting the dynamics of indicator gases in a production unit in terms of technical and geological mining conditions.

Numerous factors have an impact on coal self-heating processes. The most significant ones are the degree of coal metamorphism, petrographic content, moisture content, coal bed thickness, coal fragmentation as well as the degree of coal ventilation. The rate of air flow in goaf is very low; therefore, the heat dissipation is slow which, in turn, is conducive to the occurrence of fires. Also, a large accumulation of coal slack, along with the increase in ventilation intensity, creates favorable conditions for endogenic fire incidents. The changes of pressure are also conducive to the occurrence of fire hazard; when atmospheric pressure decreases gases are pushed out of the old goaf. In the case of the increase in atmospheric pressure, the inflow of fresh air may also result in a fire incident in goaf (Bystroń 1997; Charriere et al. 2010). The content of fire gases depends on the amount of coal, the conditions of the seat of fire and the phase of fire development. Gas sorption on coals was also reported to be influencing the gas content in mine atmosphere (Dudzińska et al. 2015, 2017) and to be related to the coal grain size (Wojtacha-Rychter et al. 2019). Pressure and temperature were also reported to be changing the sorption capacities of coals and coal-derived materials (Howaniec 2016a, b). Fragmented coal and the inflow of approximately $2 \mathrm{~m}^{3} / \mathrm{h}$ into $1 \mathrm{~m}^{3}$ of coal create the most favorable conditions for self-ignition (Davis and Bryne
1926). Mining practice has shown that it is necessary to carry on a systematic monitoring of air content as well as to determine the increase in the content of carbon monoxide, carbon dioxide, hydrocarbons, hydrogen and the decrease of oxygen content. Kim (2004) developed a methodology for determining the location and spread of combustion zones in underground coal mines. The methodology is based on the ratio of hydrocarbons concentration of higher molecular weight $\left(\mathrm{C}_{2}\right.$ do $\left.\mathrm{C}_{5}\right)$ to total hydrocarbon gases. $\mathrm{Lu}$ et al. (2017) concluded that $\mathrm{CO}$ and $\mathrm{C}_{2} \mathrm{H}_{4}$ may be applied as indicator gases in predicting coal-self ignition at a low temperature range. Zhang and Kuenzer (2007) also conducted research concerning the influence of coal and oxygen consumption during the oxidation reaction on the emissions of $\mathrm{CO}_{2}$ and $\mathrm{CO}$. The monitoring of fire gases is the main tool to determine the status of underground fire in coal mines in India (Singh et al. 2007). Adamus et al. (2011) discussed the factors which have an impact on the precision of determining the temperature of coal self-ignition in underground coal environment. The research focused on a precise interpretation of mine gases in relation to the use of laboratory verified gas characteristic of thermal oxidation of coal. Hu et al. (2015) conducted research to investigate the influence of vertical location and drainage capacity of surface hole on the self-ignition of coal in a working face gob using numerical modelling. Lu et al. (2004) presented a five-step method of fire prevention and control including the detection, prevention, sealing, injection and pressure regulation. The gradual oxygen decrease is an indicator of the development of fire source. During the fire, especially in the initial phase, there is a surplus of air. Other reactions, such as coal degasification in the neighboring zone also take place; therefore the temperature of the exhaust gases may differ. In real conditions, the source of self-heating does not have constant temperature; characteristically, the range is from the temperature of the source to the temperature of rockmass. The apparatus used in the present study allowed to achieve a range of temperatures in the research vessel. Underground fires occur in places characterized by intensive air permeation to the goaf, i.e. crushed coal. Yuan and Smith (2011) carried out studies on the influence of different ventilation rates on $\mathrm{CO}$ and $\mathrm{CO}_{2}$ emissions. This study presents the results of chromatographic analysis of the concentrations of gases emitted from the examined samples during the heating and cooling phases. The research was conducted for various types of coals in Poland taking into consideration both methane and non-methane coal beds using three rates of gas flow through the bed. The obtained results may be useful for the assessment of coal self-heating in the goafs as well as for the assessment of the status of fire hazard in the cooling fire field. 


\section{Materials and methods}

\subsection{Material}

The coal samples came from 22 Polish coal mines and were labelled from 1 to 22 . The samples were collected from a freshly unearthed body of coal, from places representing average coal bed properties in terms of endogenic fire hazard. The collected coal had the form of coal lumps with the largest mass possible. Next, the samples were sprinkled with coal dust, placed in an airtight container and sealed. Before the tests were performed, the samples had been crushed in a screw crusher. The research material consisted of coal lumps of $2.5 \mathrm{~mm}$ grainsize with the amount of $6.5 \mathrm{~kg}$. They were placed in a metal container and flushed with nitrogen. Then, a sieve analysis of the samples in analytical state was performed (Table 1).

The determined values of physico-chemical parameters of the tested coal samples are presented in Table 2.

\subsection{Methods}

\subsubsection{The experimental set-up}

The research on the oxidation and cooling processes was carried out in a metal reactor chamber of a shape approximating a sphere (Fig. 1). The fragmented coal is placed inside the sphere, during the self-heating phase synthetic air flows through the grains whereas during the cooling process nitrogen. The temperature is increased by means of a heater made from a heating cable shaped as a loose spiral with a diameter of $40 \mathrm{~mm}$ and height of $40 \mathrm{~mm}$. The spaces between the coils of the cable were filled with ground coal which forms a cylindrical sample with temperature determined by means of the temperature regulating system. The predetermined temperatures for the selfheating phase were 50,150 and $250{ }^{\circ} \mathrm{C}$ while for the cooling phase $250,150,50$ and $35^{\circ} \mathrm{C}$. Two channels ensure the inflow of gas mixture to the place of coal heating. The processes of increasing and decreasing the temperature of coal run slowly, the experiment lasts a few days. Heat losses are determined on the basis of the dimensions and the measured values of six temperatures (the first measurement is performed in the source of coal heating, the second one at a distance of $40 \mathrm{~mm}$ from the central part of the core of the source of heating, the third one at a distance of $60 \mathrm{~mm}$, the forth one at the distance of $80 \mathrm{~mm}$, the fifth at the distance of $100 \mathrm{~mm}$ and the sixth one at the distance of $120 \mathrm{~mm}$ ). The damping of temperature fluctuations is achieved by applying sufficiently large heat capacity (coal mass of approximately $6.5 \mathrm{~kg}$ ). The apparatus was equipped with six temperature detectors; the detector which is centrally located controls the heating process by means of a PID controller. The temperature measurement during the reaction is performed with the precision to $0.2{ }^{\circ} \mathrm{C}$; the measurement results are automatically recorded on a computer disc. The gas with predetermined $20.5 \%$ oxygen content flows through the coal placed in the reaction chamber. The air flow was controlled at the inlet and outlet using respectively the ALICAT2005CCM-D and ALICAT M-200SCCM-D/5 M flow controllers.

The analysis of the gas content was performed by means of the following chromatographs:

- Chromatograph Shimadzu GC 2014 with a TCD and a molecular sieve column for measuring hydrogen concentration. Argon was used as a carrier gas.

- Chromatograph Shimadzu GC 2014 with a TCD, a molecular sieve column and a Porapack column for measuring the concentrations of oxygen, nitrogen, methane, carbon dioxide, and carbon monoxide. Helium was used as a carrier gas.

- Chromatograph Shimadzu GC 17A with TCD, a methanizer, a FID, a molecular sieve capillary column and a Porapack column for measuring the concentration of carbon monoxide. Helium was used as a carrier gas.

- Chromatograph Fisons GC 8000 S with a FID, a modified activated carbon column and an alumel column for measuring the concentrations of ethane, ethylene, propane and acetylene. Helium was used as a carrier gas.

Gas tests were performed according to Polish standard PN-74/Z-04094/02-Clean air protection and accredited laboratory research procedures:

- BD-3/ZLGIG/PB-CO.04 issue 1 of 25.01.2010-Determining trace content of carbon monoxide in gas samples.

- BD-3/ZLGIG/PB-TL.05 issue 1 of 25.01.2010-Determining the composition of a gas sample using gas chromatography.

- BD-3/ZLGIG/PB-WO.06 issue 2 of 13.06.2014Determining hydrogen content in a gas sample.

- BD-3/ZLGIG/PB-AE.07 issue 1 of 25.01.2010-Determining acetylene and ethylene content in a gas sample.

- BD-3/ZLGIG/PB-WN.08 issue 1 of 25.01.2010Determining the content of C2-C4 hydrocarbons in a gas sample.

\subsubsection{Research procedure}

The coal samples placed in the reaction chamber were analyzed for three flow rates of synthetic air and nitrogen, i.e. $V=4.0,8.0$ and $12.0 \mathrm{dm}^{3} / \mathrm{h}$. The first phase of the 
Table 1 Sieve analysis results for the tested coal samples

\begin{tabular}{|c|c|c|c|c|c|c|c|c|c|}
\hline \multirow[t]{2}{*}{ Sample no } & \multirow[t]{2}{*}{ Parameter } & \multicolumn{8}{|c|}{ Grain size (mm) } \\
\hline & & $>2$ & $2-1$ & $1-0.7$ & $0.7-0.5$ & $0.5-0.35$ & $0.35-0.25$ & $0.25-0.125$ & $<0.125$ \\
\hline \multirow[t]{2}{*}{1} & Mass (g) & 3 & 90.4 & 43.6 & 37 & 23 & 25 & 27 & 30 \\
\hline & Percentage (\%) & 1.1 & 32.4 & 15.6 & 13.3 & 8.2 & 9 & 9.7 & 10.7 \\
\hline \multirow[t]{2}{*}{2} & Mass (g) & 2 & 90 & 45 & 33 & 20 & 22 & 20 & 24 \\
\hline & Percentage (\%) & 0.8 & 35.2 & 17.6 & 12.9 & 7.8 & 8.6 & 7.8 & 9.4 \\
\hline \multirow[t]{2}{*}{3} & Mass (g) & 4 & 80 & 44 & 37 & 32 & 27 & 25 & 30 \\
\hline & Percentage $(\%)$ & 1.4 & 28.7 & 15.8 & 13.1 & 11.5 & 9.7 & 9 & 10.8 \\
\hline \multirow[t]{2}{*}{4} & Mass (g) & 7 & 99.5 & 55 & 40 & 25 & 20 & 19 & 15 \\
\hline & Percentage $(\%)$ & 2.5 & 35.5 & 19.6 & 14.3 & 8.9 & 7.1 & 6.8 & 5.3 \\
\hline \multirow[t]{2}{*}{5} & Mass (g) & 3 & 70 & 47 & 39 & 44 & 37 & 20 & 44 \\
\hline & Percentage $(\%)$ & 1 & 23 & 15.5 & 12.8 & 14.4 & 12.2 & 6.6 & 14.5 \\
\hline \multirow[t]{2}{*}{6} & Mass (g) & 4 & 72 & 50 & 38 & 47 & 38 & 23 & 40 \\
\hline & Percentage $(\%)$ & 1.3 & 23 & 16 & 12.2 & 15.1 & 12.2 & 7.4 & 12.8 \\
\hline \multirow[t]{2}{*}{7} & Mass (g) & 4 & 82 & 39 & 32 & 20 & 23 & 30 & 32 \\
\hline & Percentage $(\%)$ & 1.6 & 31.3 & 14.9 & 12.2 & 7.6 & 8.8 & 11.4 & 12.2 \\
\hline \multirow[t]{2}{*}{8} & Mass (g) & 10 & 90 & 60 & 53 & 31 & 23 & 21 & 19 \\
\hline & Percentage $(\%)$ & 3.3 & 29.3 & 19.5 & 17.3 & 10.1 & 7.5 & 6.8 & 6.2 \\
\hline \multirow[t]{2}{*}{9} & Mass (g) & 3 & 80 & 40 & 35 & 23 & 29 & 33 & 31 \\
\hline & Percentage $(\%)$ & 1.1 & 29.2 & 14.6 & 12.8 & 8.4 & 10.6 & 12 & 11.3 \\
\hline \multirow[t]{2}{*}{10} & Mass (g) & 11 & 84 & 57 & 59 & 37 & 24 & 19 & 15 \\
\hline & Percentage $(\%)$ & 3.6 & 27.4 & 18.6 & 19.3 & 12.1 & 7.8 & 6.3 & 4.9 \\
\hline \multirow[t]{2}{*}{11} & Mass (g) & 7 & 81 & 50 & 62 & 41 & 27 & 20 & 17 \\
\hline & Percentage $(\%)$ & 2.3 & 26.6 & 16.4 & 20.3 & 13.4 & 8.9 & 6.6 & 5.5 \\
\hline \multirow[t]{2}{*}{12} & Mass (g) & 5.0 & 71.0 & 39.0 & 44.0 & 33.0 & 29.0 & 27.0 & 43.0 \\
\hline & Percentage $(\%)$ & 1.7 & 24.4 & 13.4 & 15.1 & 11.3 & 10.0 & 9.3 & 14.8 \\
\hline \multirow[t]{2}{*}{13} & Mass (g) & 4.0 & 77.0 & 40.0 & 41.0 & 26.0 & 30.0 & 26.0 & 31.0 \\
\hline & Percentage $(\%)$ & 1.5 & 28.0 & 14.5 & 14.9 & 9.5 & 10.9 & 9.5 & 11.3 \\
\hline \multirow[t]{2}{*}{14} & Mass (g) & 7.0 & 70.0 & 47.0 & 49.0 & 33.0 & 39.0 & 31.0 & 47.0 \\
\hline & Percentage $(\%)$ & 2.2 & 21.7 & 14.6 & 15.2 & 10.2 & 12.1 & 9.6 & 14.6 \\
\hline \multirow[t]{2}{*}{15} & Mass (g) & 3.0 & 67.0 & 50.0 & 41.0 & 39.0 & 36.0 & 29.0 & 37.0 \\
\hline & Percentage $(\%)$ & 1.0 & 22.2 & 16.6 & 13.6 & 12.9 & 11.9 & 9.6 & 12.3 \\
\hline \multirow[t]{2}{*}{16} & Mass (g) & 6.0 & 72.0 & 57.0 & 39.0 & 42.0 & 44.0 & 33.0 & 40.0 \\
\hline & Percentage $(\%)$ & 1.8 & 21.6 & 17.1 & 11.7 & 12.6 & 13.2 & 9.9 & 12.0 \\
\hline \multirow[t]{2}{*}{17} & Mass (g) & 4.0 & 70.0 & 53.0 & 42.0 & 48.0 & 40.0 & 30.0 & 47.0 \\
\hline & Percentage $(\%)$ & 1.2 & 21.0 & 15.9 & 12.6 & 14.4 & 12.0 & 9.0 & 14.1 \\
\hline \multirow[t]{2}{*}{18} & Mass (g) & 3.0 & 63.0 & 48.0 & 37.0 & 33.0 & 32.0 & 27.0 & 33.0 \\
\hline & Percentage $(\%)$ & 1.1 & 22.8 & 17.4 & 13.4 & 12.0 & 11.6 & 9.8 & 12.0 \\
\hline 19 & Mass (g) & 4.0 & 64.0 & 50.0 & 40.0 & 30.0 & 27.0 & 22.0 & 26.0 \\
\hline & Percentage $(\%)$ & 1.5 & 24.3 & 19.0 & 15.2 & 11.4 & 10.3 & 8.4 & 9.9 \\
\hline 20 & Mass (g) & 6.0 & 72.0 & 39.0 & 40.0 & 23.0 & 28.0 & 24.0 & 30.0 \\
\hline & Percentage $(\%)$ & 2.3 & 27.5 & 14.9 & 15.3 & 8.8 & 10.7 & 9.2 & 11.5 \\
\hline 21 & Mass (g) & 8.0 & 95.0 & 54.0 & 29.0 & 21.0 & 20.0 & 18.0 & 16.0 \\
\hline & Percentage (\%) & 3.1 & 36.4 & 20.7 & 11.1 & 8.0 & 7.7 & 6.9 & 6.1 \\
\hline 22 & Mass (g) & 5.0 & 70.0 & 52.0 & 41.0 & 47.0 & 45.0 & 36.0 & 37.0 \\
\hline & Percentage $(\%)$ & 1.5 & 21.0 & 15.6 & 12.3 & 14.1 & 13.5 & 10.8 & 11.1 \\
\hline
\end{tabular}


Table 2 Physico-chemical parameters of the tested coal samples

\begin{tabular}{|c|c|c|c|c|c|c|c|c|c|c|c|c|}
\hline \multirow{2}{*}{$\begin{array}{l}\text { Sample } \\
\text { no }\end{array}$} & \multirow{2}{*}{$\begin{array}{l}\text { Transient } \\
\text { moisture } \\
\text { content }{ }^{1} \\
\text { (\% } \\
\text { weight) }\end{array}$} & \multirow{2}{*}{$\begin{array}{l}\text { Moisture } \\
\text { content in } \\
\text { analytical } \\
\text { sample }^{1} \\
\text { (\% } \\
\text { weight) }\end{array}$} & \multirow{2}{*}{$\begin{array}{l}\text { Ash } \\
\text { content }^{2} \\
(\% \\
\text { weight })\end{array}$} & \multirow{2}{*}{$\begin{array}{l}\text { Volatile } \\
\text { matter } \\
\text { content }^{3} \\
(\% \\
\text { weight })\end{array}$} & \multirow{2}{*}{$\begin{array}{l}\text { Total } \\
\text { carbon } \\
\text { content }^{4} \\
(\% \\
\text { weight) }\end{array}$} & \multirow{2}{*}{$\begin{array}{l}\text { Total } \\
\text { sulphur } \\
\text { content }^{5} \\
\text { (\% } \\
\text { weight) }\end{array}$} & \multirow{2}{*}{$\begin{array}{l}\text { Total } \\
\text { hydrogen } \\
\text { content }{ }^{4} \\
\text { (\% } \\
\text { weight) }\end{array}$} & \multirow{2}{*}{$\begin{array}{l}\text { Nitrogen } \\
\text { content }{ }^{4} \\
\text { (\% } \\
\text { weight) }\end{array}$} & \multirow{2}{*}{$\begin{array}{l}\text { Oxygen } \\
\text { content } \\
(\% \\
\text { weight })\end{array}$} & \multicolumn{3}{|c|}{ Self-ignition index ${ }^{6}$} \\
\hline & & & & & & & & & & $\begin{array}{l}\mathrm{A} \\
\mathrm{kJ} / \mathrm{mol}\end{array}$ & $\begin{array}{l}\mathrm{Sz}^{\mathrm{a}} \\
{ }^{\circ} \mathrm{C} / \\
\mathrm{min}\end{array}$ & $\begin{array}{l}\text { Self- } \\
\text { ignition } \\
\text { group }\end{array}$ \\
\hline 1 & 1.72 & 1.9 & 7.4 & 29.4 & 75.12 & 0.52 & 4.37 & 1.29 & 6.44 & 65 & 61 & II \\
\hline 2 & 2.42 & 1.9 & 5.25 & 30.9 & 79.6 & 0.32 & 4.2 & 1.57 & 5.1 & 61 & 74 & II \\
\hline 3 & 1.2 & 0.8 & 4.2 & 23 & 87.8 & 0.48 & 3.2 & 1.13 & 8.3 & 60 & 42 & II \\
\hline 4 & 8.2 & 9.2 & 4.9 & 35.5 & 68.2 & 0.81 & 4.7 & 1.2 & 10.9 & 40 & 128 & $\mathrm{~V}$ \\
\hline 5 & 1.5 & 0.9 & 3.8 & 26.5 & 83.5 & 0.21 & 4.8 & 1.6 & 4.4 & 61 & 52 & II \\
\hline 6 & 1.6 & 1.1 & 3.9 & 26.1 & 84.2 & 0.41 & 3.97 & 1.52 & 6.2 & 64 & 61 & II \\
\hline 7 & 1.9 & 1.7 & 6.4 & 28.1 & 81.9 & 0.48 & 4.6 & 1.7 & 4.5 & 58 & 53 & II \\
\hline 8 & 7.1 & 8.0 & 5.4 & 34 & 69.5 & 0.75 & 4.8 & 1.1 & 11.42 & 47 & 125 & $\mathrm{~V}$ \\
\hline 9 & 1.8 & 1.6 & 4.7 & 28.7 & 81.7 & 0.49 & 4.2 & 1.45 & 4.9 & 57 & 76 & II \\
\hline 10 & 8.8 & 9.2 & 4.9 & 34.1 & 70.6 & 1.1 & 4.72 & 0.79 & 12.28 & 47 & 135 & $\mathrm{~V}$ \\
\hline 11 & 3.6 & 5.2 & 4.5 & 35.6 & 75.1 & 0.52 & 4.7 & 1.2 & 10.5 & 50 & 110 & IV \\
\hline 12 & 1.4 & 1.1 & 4.1 & 24.5 & 83.5 & 0.3 & 4.4 & 1.45 & 3.5 & 62 & 53 & II \\
\hline 13 & 1.2 & 0.8 & 4.2 & 23 & 87.8 & 0.48 & 3.2 & 1.13 & 8.3 & 60 & 42 & II \\
\hline 14 & 3.6 & 4.4 & 8.2 & 32.1 & 72.7 & 0.88 & 4.7 & 1.3 & 7.6 & 52 & 105 & IV \\
\hline 15 & 1.8 & 1.1 & 4.1 & 22.9 & 88.1 & 0.51 & 4.62 & 1.21 & 4.18 & 66 & 45 & I \\
\hline 16 & 1.9 & 1.8 & 14.2 & 28.6 & 71.2 & 3.4 & 3.3 & 1.27 & 6.2 & 61 & 87 & III \\
\hline 17 & 3.7 & 5.1 & 5.5 & 34.1 & 74.7 & 0.6 & 4.47 & 1.25 & 10.4 & 47 & 103 & IV \\
\hline 18 & 1.5 & 1.1 & 4.2 & 26.2 & 84.3 & 0.29 & 4.2 & 1.3 & 5.88 & 64 & 56 & II \\
\hline 19 & 3.2 & 4.3 & 4.2 & 36.2 & 74.5 & 1.4 & 4.8 & 1.7 & 8.1 & 52 & 108 & IV \\
\hline 20 & 3.5 & 4.2 & 7.9 & 31.8 & 73.05 & 0.78 & 4.5 & 1.35 & 7.5 & 51 & 97 & III \\
\hline 21 & 8.0 & 9.0 & 4.5 & 35.2 & 68.5 & 0.78 & 4.7 & 1.2 & 10.8 & 41 & 127 & V \\
\hline 22 & 1.9 & 1.6 & 4.8 & 28.5 & 81.2 & 0.52 & 4.2 & 1.37 & 4.7 & 58 & 72 & II \\
\hline
\end{tabular}

${ }^{1}$ Solid fuels. Determining moisture content - PN-G-04511:1980, item 2.1

${ }^{2}$ Solid fuels. Determining moisture content, volatile matter and ash using an automatic analyzer - PN-G-04560:1998

${ }^{3}$ Solid fuels. Determining volatile matter content using a gravimetric method - PN-G-04516:1998

${ }^{4}$ Solid fuels. Determining the content of carbon, hydrogen and nitrogen using automatic analyzers- PN-G-04571:1998

${ }^{5}$ Solid fuels. Determining the content of total sulphur and ash sulphur using automatic analyzers - PN-G-04584:2001

${ }^{6}$ Bituminous coal. Determining the index of self-ignition-PN-93/G-04558

experiment consisted in analyzing gas concentrations in a $20.5 \%$ oxygen content atmosphere which is the value approximating the oxygen content in circulating air current of longwall face in coal mines. The outlet gas was analyzed at the following temperatures: 50,150 and $250{ }^{\circ} \mathrm{C}$. The second phase involved analyzing the gas concentrations in nitrogen atmosphere which reflects the nitrogen-rich atmosphere of goaf spaces during the phase of the fire hot spot cooling. The outlet gas was analyzed at $250,150,50$ and $35^{\circ} \mathrm{C}$. The experiment was terminated when a coal sample reached the final temperature $\mathrm{T}=35^{\circ} \mathrm{C}$ which is assumed to be the average rock-mass temperature in coal mines. The summary of the process conditions configurations adopted in the research procedure is given in Table 3.

\section{Results and discussion}

With the increase of the temperature in the coal heating hot-spot, the concentrations of ethane, ethylene, propane, propylene, acetylene, carbon monoxide, carbon dioxide and hydrogen increase while the oxygen content decreases 


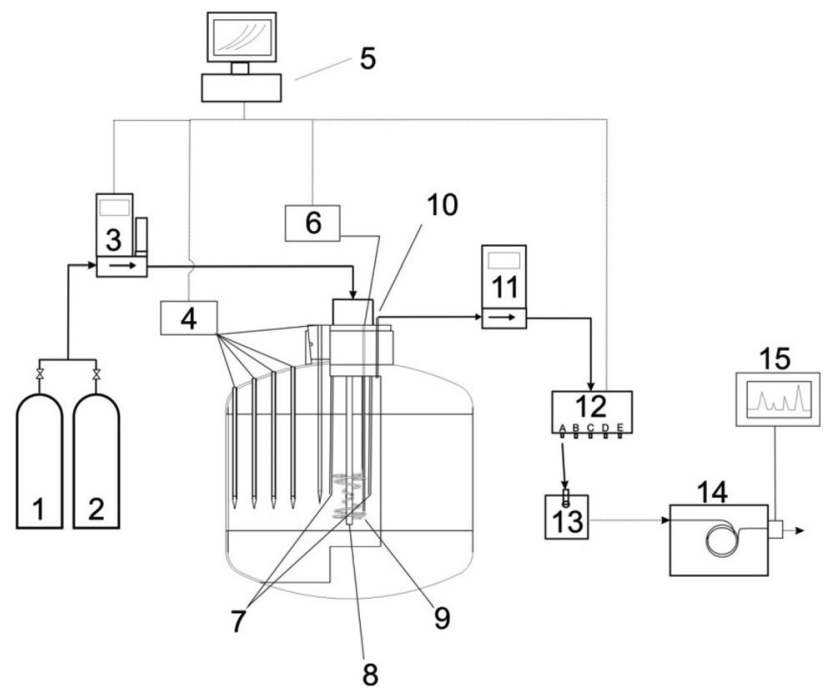

Fig. 1 Test stand for fire monitoring during the heating and cooling phases. 1-synthetic air, 2-nitrogen, 3-gas flowmeter and flow regulator, 4-thermocouples nos 2-6, 5-temperature, flow rate and gas sampling controller, 6-temperature recording, 7-air inlets, 8-thermocouple no 1, 9-heating zone, 10-gas outlets, 11-outlet gas flowmeter, 12-automatic gas sampling device, 13-Tedlar bag, 14-gas chromatographs, 15 -gas concentrations recording

(Beamish and Arisoy 2008; Singh et al. 2007; Lu et al. 2004). With the decrease of coal temperature, the concentrations of the analyzed gases demonstrate downward tendency. The presence of fire gases and their relative proportions depend on the flow of the coal heating process itself as well as on the accompanying processes. The heating process may run in a different way, which is connected with the conditions in which it occurs. In the case of decreasing the air supply to the hot spot, the content of emitted gases reflects the distillation process and depends mainly on the temperature and the type of coal.

The analysis of the composition of gases emitted in the heating and cooling phases was performed for 22 coal samples. The tests were carried out for three rates of gas flow. Graphic representation of all the tested gases for the 22 coal samples would require several hundred of charts for the three variants of flow rates. Therefore, in order to present the general trends, sample number 1 was selected. The charts of the compositions of particular gases are presented in Fig. 2.

In underground mining, coal mine ventilation has an influence on gas concentrations and the relevant fire indices which are used for the assessment of fire hazard status. There is a codependence between the increase in $\mathrm{CO}_{2}$ and $\mathrm{CO}$ and the decrease of oxygen content. This is the reason why the $\mathrm{CO} / \mathrm{CO}_{2}$ index, which has been used in Poland for several decades, was selected. As shown in Fig. 3, the

Table 3 Summary of the process conditions configurations

\begin{tabular}{|c|c|c|c|}
\hline No & Gas flowing through coal deposit & Gas flow rate $\left(\mathrm{dm}^{3} / \mathrm{h}\right)$ & Coal bed temperature $\left({ }^{\circ} \mathrm{C}\right)$ \\
\hline 1 & Synthetic air & 4 & 50 \\
\hline 2 & Synthetic air & 8 & 50 \\
\hline 3 & Synthetic air & 12 & 50 \\
\hline 4 & Synthetic air & 4 & 150 \\
\hline 5 & Synthetic air & 8 & 150 \\
\hline 6 & Synthetic air & 12 & 150 \\
\hline 7 & Synthetic air & 4 & 250 \\
\hline 8 & Synthetic air & 8 & 250 \\
\hline 9 & Synthetic air & 12 & 250 \\
\hline 10 & Nitrogen & 4 & 250 \\
\hline 11 & Nitrogen & 8 & 250 \\
\hline 12 & Nitrogen & 12 & 250 \\
\hline 13 & Nitrogen & 4 & 150 \\
\hline 14 & Nitrogen & 8 & 150 \\
\hline 15 & Nitrogen & 12 & 150 \\
\hline 16 & Nitrogen & 4 & 50 \\
\hline 17 & Nitrogen & 8 & 50 \\
\hline 18 & Nitrogen & 12 & 50 \\
\hline 19 & Nitrogen & 4 & 35 \\
\hline 20 & Nitrogen & 8 & 35 \\
\hline 21 & Nitrogen & 12 & 35 \\
\hline
\end{tabular}



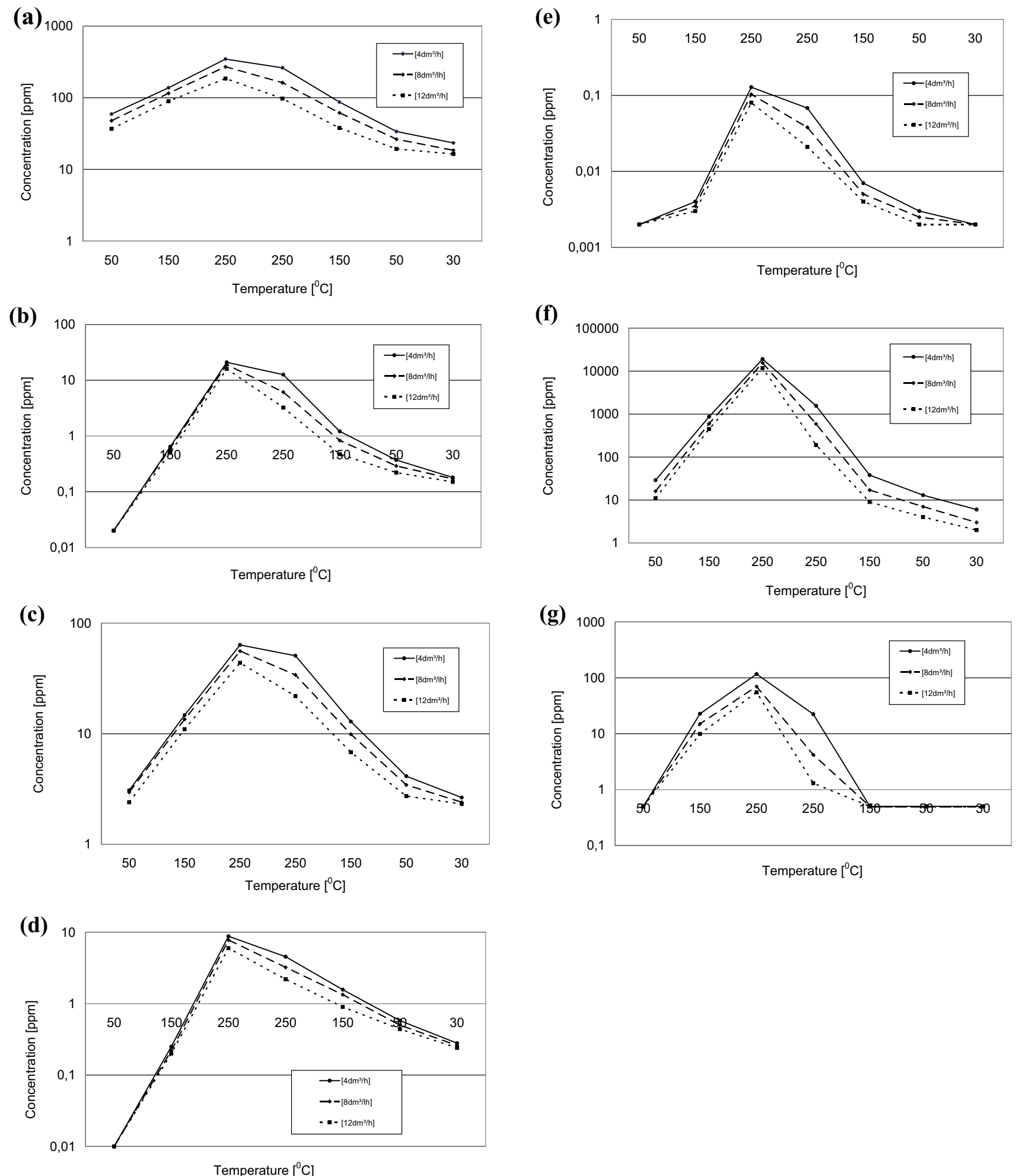

Fig. 2 Changes in the concentrations of gases during the heating and cooling phase: a ethane, $\mathbf{b}$ ethylene, $\mathbf{c}$ propane, $\mathbf{d}$ propylene, $\mathbf{e}$ acetylene, f carbon monoxide, $\mathbf{g}$ hydrogen for the flow rates of $4.0,8.0$ and $12.0 \mathrm{dm}^{3} / \mathrm{h}$ 


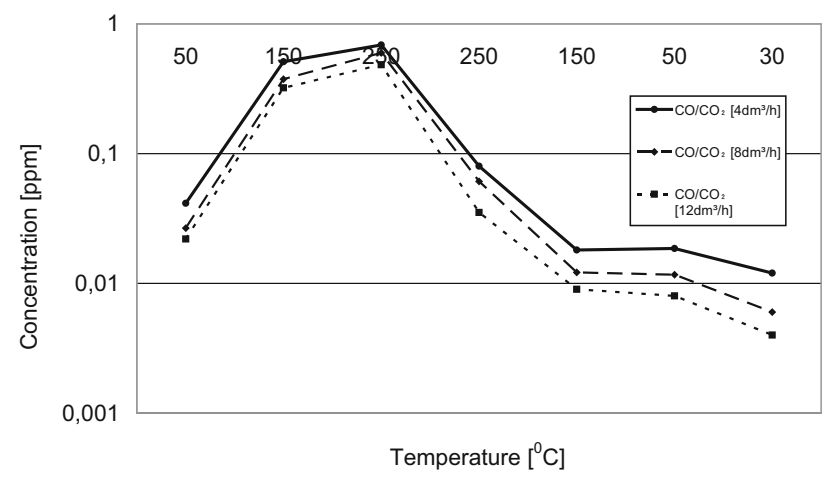

Fig. 3 Changes in $\mathrm{CO}$ to $\mathrm{CO}_{2}$ proportion during the heating and cooling phase for the flow rates of $4.0,8.0$ and $12.0 \mathrm{dm}^{3} / \mathrm{h}$

index increases with the increase in temperature approaching the value of 1 whereas during the cooling phase it drops to the value of 0.01. Yuan and Smith (2011) carried out research on the impact of ventilation rates using an exothermic furnace for the rates ranging from 100 to $500 \mathrm{~cm}^{3} / \mathrm{min}$. The laboratory tests were performed at the temperatures of 70,90 and $100{ }^{\circ} \mathrm{C}$. At the initial temperature of $70{ }^{\circ} \mathrm{C}$ the amounts of $\mathrm{CO}$ generated under different airflow rates were approximately the same, but increased significantly with the increase in initial temperatures and airflow rates. The concentrations of $\mathrm{CO}$ presented in Fig. $2 \mathrm{f}$ show that during the heating phase, the amount of $\mathrm{CO}$ significantly increases with rising temperature and the change of air flow rate. Based on the analysis of all 22 coal samples, significant differences in the concentration quotients of the analyzed gases were observed with the changes in the flow rates of synthetic air and nitrogen. Zhang et al. (2015) conducted research on carbon oxide emissions for different coal classes at the temperature above $200{ }^{\circ} \mathrm{C}$. Based on the impact of coal mass and oxygen consumption on $\mathrm{CO}_{2}$ and $\mathrm{CO}$ emissions during the oxidation reaction, it was noticed that coal oxides are formed as a result of not only the decomposition of surface oxides caused by the reaction but also of the oxygen containing groups in the coal matrix. Figure 4 presents the charts of concentration quotients for gases obtained at flow rates of synthetic air and nitrogen of $8 \mathrm{dm}^{3} / \mathrm{h}$ and $12 \mathrm{dm}^{3} / \mathrm{h}$ respectively in relation to the concentrations obtained with the flow rate of $4 \mathrm{dm}^{3} / \mathrm{h}$ for sample number 1 .
The proportions of the concentrations of ethane, ethylene, propane, propylene, acetylene, carbon monoxide and hydrogen for the heating phase showed a downward tendency with the increase in temperature whereas for the cooling phase an upward tendency with the temperature decrease. The proportions of carbon monoxide concentrations, shown in Fig. 4f, with the increase and decrease of temperature demonstrated an upward tendency. According to the above scheme, 22 coal samples were analyzed and juxtaposed in two variants. The first variant presents the concentration quotients of the gases flowing out of the reactor at the flow rate of $8 \mathrm{dm}^{3} / \mathrm{h}$ in relation to the concentrations of gases flowing from the reactor at the rate of $4 \mathrm{dm}^{3} / \mathrm{h}$ (Fig. 5 and Table 4). The other one displays the relation of the concentration of gases flowing from the reactor at the rate of $12 \mathrm{dm}^{3} / \mathrm{h}$ to the concentrations of gases flowing from the reactor at the rate of $4 \mathrm{dm}^{3} / \mathrm{h}$ (Fig. 6 and Table 5).

The concentrations of some gases determined at the temperature of $50{ }^{\circ} \mathrm{C}$ (e.g. for acetylene) are very low and equal to the Lower Limit of Quantification of a given gas. This explains why some of the concentration quotients obtained for this temperature equal 1 . With the increase of temperature up to $150{ }^{\circ} \mathrm{C}$ all proportions between the gases decreased. For the temperature of $250{ }^{\circ} \mathrm{C}$, the proportions of ethane, ethylene, propane and acetylene were subject to further decrease. In the case of carbon monoxide, the proportions increased. By contrast, for hydrogen, the proportions remained at a similar level. Values obtained during the cooling phase at the temperature of $250{ }^{\circ} \mathrm{C}$ dropped to the lowest level for all the gases. The largest decrease was observed for carbon monoxide and hydrogen. The proportions obtained at the temperature of 150,50 and $30{ }^{\circ} \mathrm{C}$ showed an upward tendency. For the cooling phase, there was an upward tendency for the concentration quotients for all gases. The proportions of gas concentrations between $12 \mathrm{dm}^{3} / \mathrm{h}$ and $4 \mathrm{dm}^{3} / \mathrm{h}$ are presented below.

With the increase of temperature up to $150{ }^{\circ} \mathrm{C}$ all proportions between the gases decreased. The smallest changes were observed for carbon monoxide (Fig. 5 (f)). Like with the synthetic air and nitrogen flow rate of $8 \mathrm{dm}^{3} / \mathrm{h}$, also at the flow rate of $12 \mathrm{dm}^{3} / \mathrm{h}$ and the temperature of $250{ }^{\circ} \mathrm{C}$ the proportions of ethane, ethylene, propane and acetylene were subject to further decrease. In the case of carbon monoxide and hydrogen, the proportions increased. 
(a)

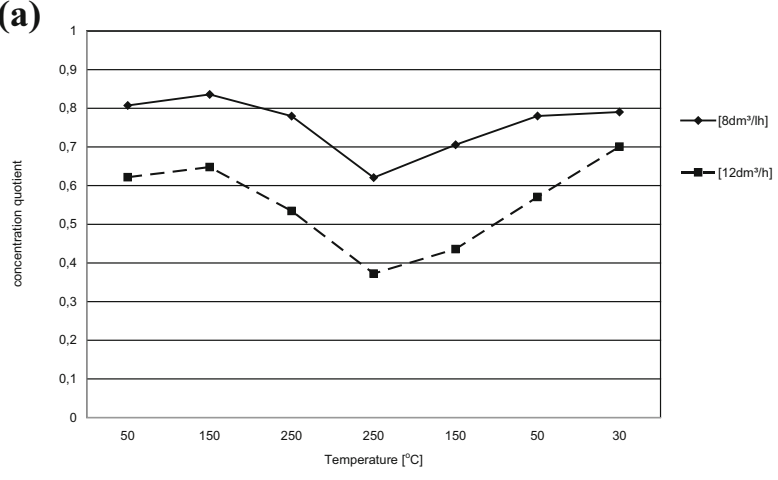

(b)

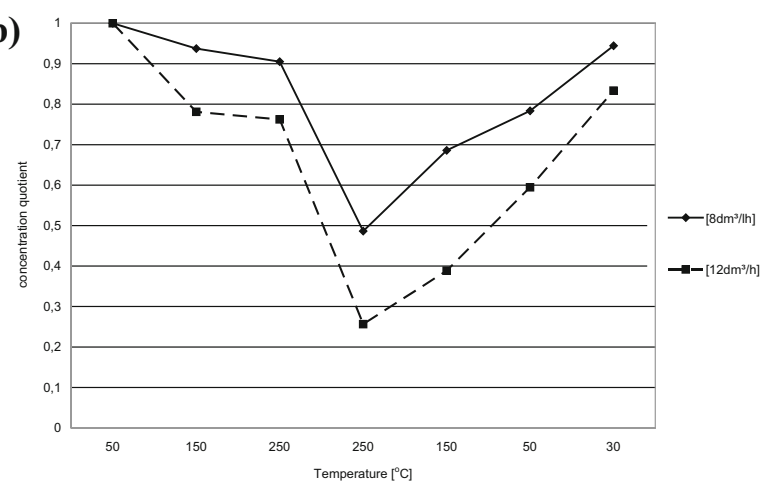

(c)
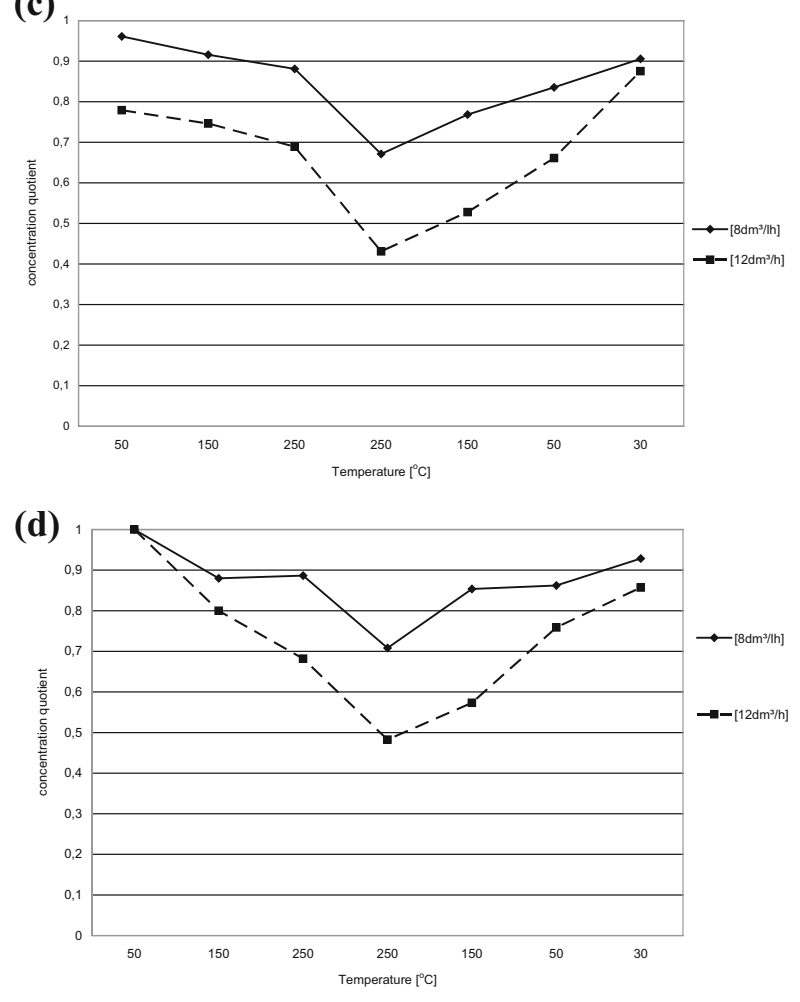

(e)
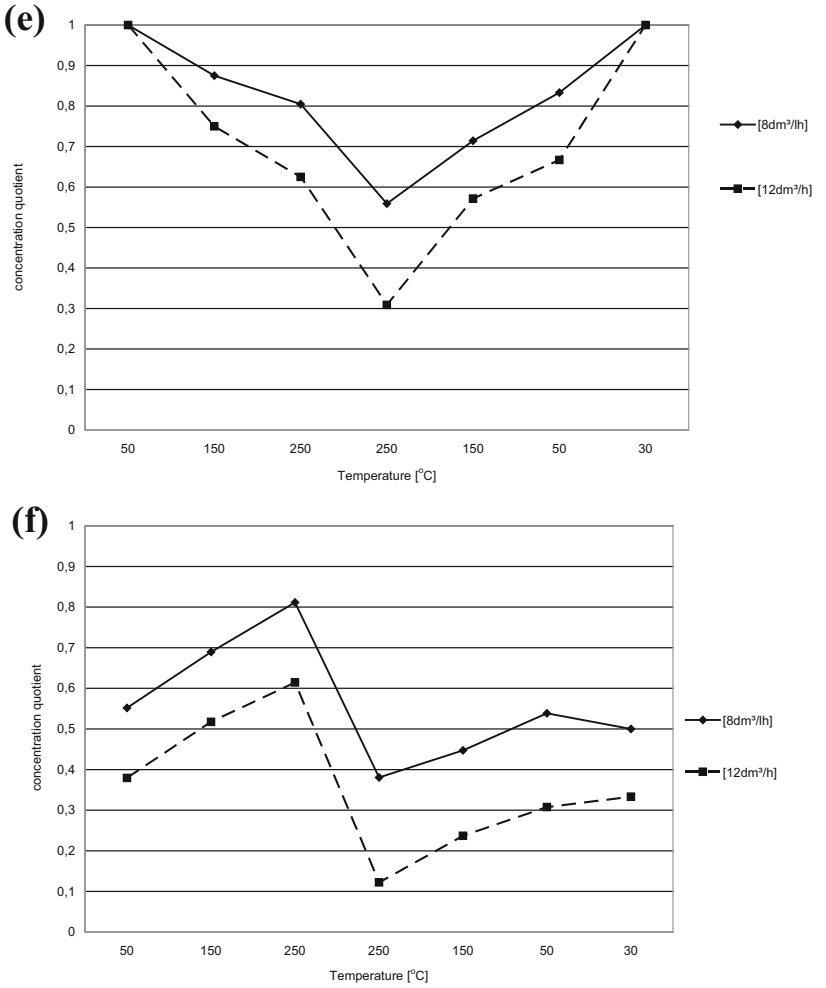

(g)

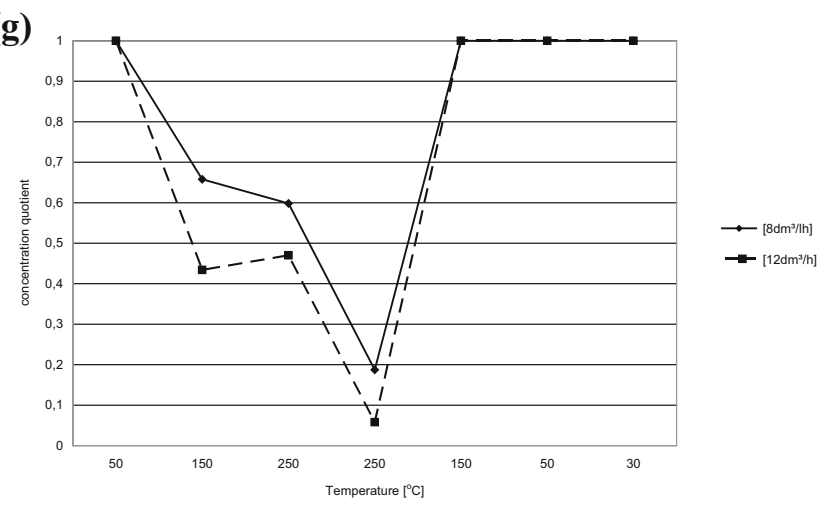

Fig. 4 Changes in concentration quotients of gases flowing from the reactor during the heating and cooling phases at the flow rates of synthetic air and nitrogen of $8 \mathrm{dm}^{3} / \mathrm{h}$ and $12 \mathrm{dm}^{3} / \mathrm{h}$ in relation to the concentrations obtained with the flow rate of $4 \mathrm{dm}^{3} / \mathrm{h}$ for sample number 1 : a ethane, b ethylene, $\mathbf{c}$ propane, $\mathbf{d}$ propylene, $\mathbf{e}$ acetylene, $\mathbf{f}$ carbon monoxide, $\mathbf{g}$ hydrogen 

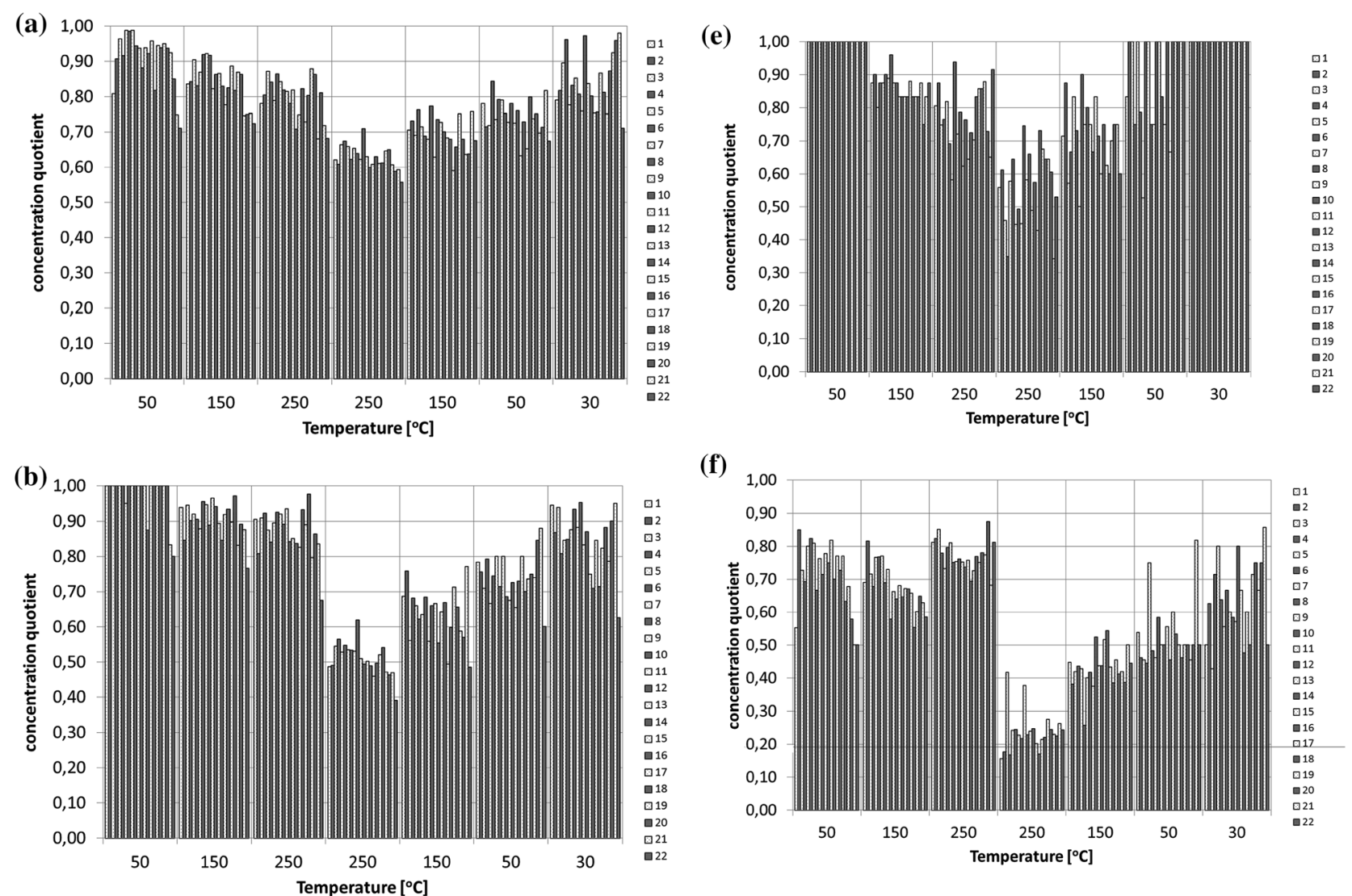

(f)
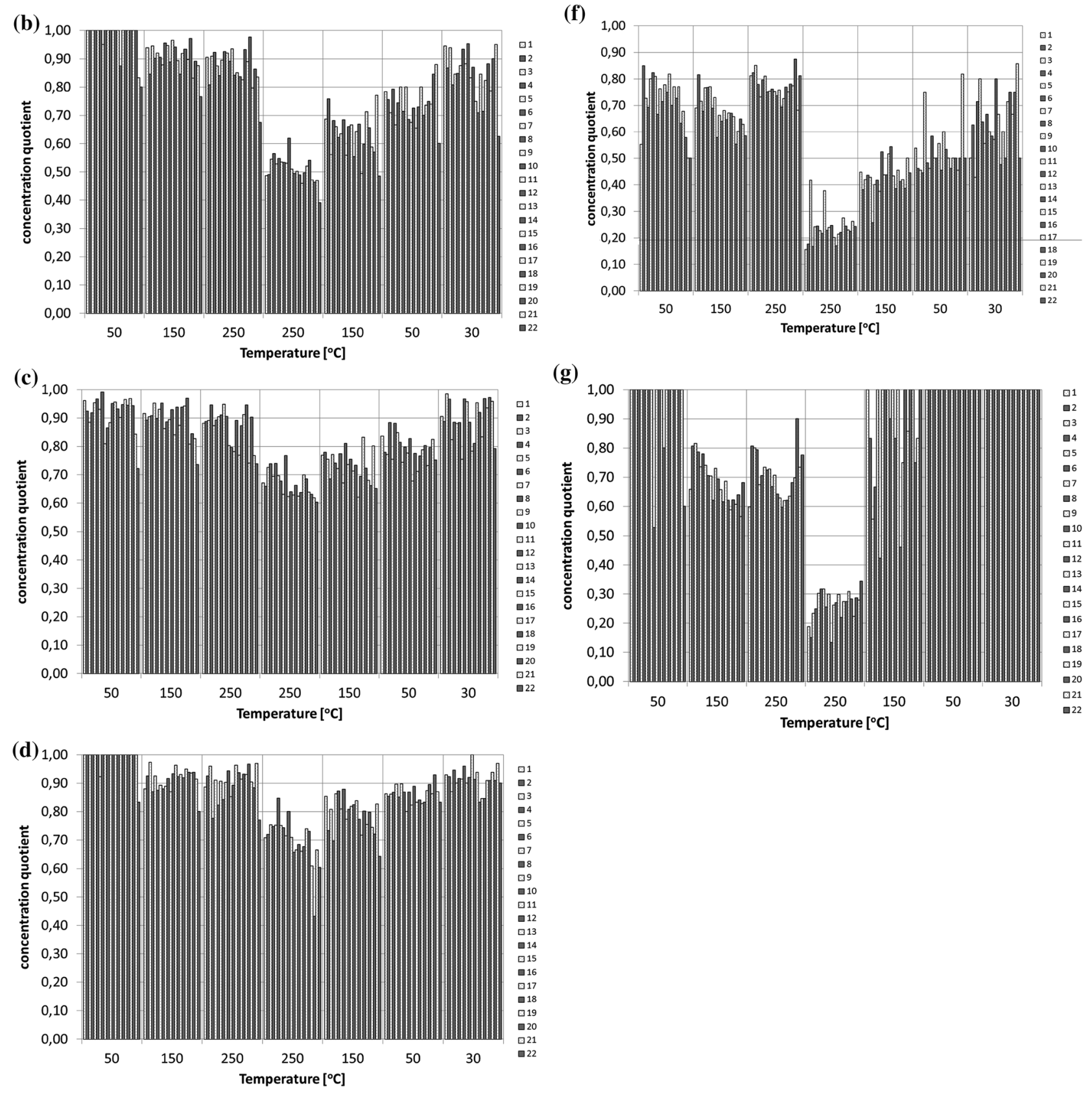
4Fig. 5 Changes in the proportions between the concentrations of gases flowing from the reactor at the flow rate of synthetic air and nitrogen of $8 \mathrm{dm}^{3} / \mathrm{h}$ and the concentrations obtained at the flow rate of $4 \mathrm{dm}^{3} / \mathrm{h}$ for heating and cooling phases: a ethane, b ethylene, c propane, $\mathbf{d}$ propylene, $\mathbf{e}$ acetylene, $\mathbf{f}$ carbon monoxide, $\mathbf{g}$ hydrogen

Values obtained during the cooling phase at the temperature of $250{ }^{\circ} \mathrm{C}$ dropped to the lowest level for all the gases. The largest decrease was observed for carbon monoxide and hydrogen. The proportions of concentrations obtained at the temperatures of 150,50 and $30{ }^{\circ} \mathrm{C}$ continued to show an upward tendency. For the cooling phase, an increase of the concentration proportions was observed. The changes in the values of the $\mathrm{CO} / \mathrm{CO}_{2}$ index for the heating and cooling phases are presented in Fig. 7 whereas their maximum and minimum values are given in Table 6 .

With the temperature increase, the minimum and maximum values of the index for all the 22 coal samples increased for every flow rate whereas with decreasing temperature the values also decreased. In the study conducted by Yuan and Smith (2011), it was stated that the ratio of $\mathrm{CO} / \mathrm{CO}_{2}$ at the temperature of $70{ }^{\circ} \mathrm{C}$ was independent of the air flow rate, approximating the constant value of 0.2 . In the present study, the index value of 0.2 was obtained in the temperature range of 50 and $150{ }^{\circ} \mathrm{C}$; however, it was observed that the changes of the flow rate have an impact on the value of the index.

Table 4 Minimum and maximum values of gas concentration quotients determined for the synthetic air and nitrogen flow rates of $8 \mathrm{dm} / \mathrm{h}$ and $4 \mathrm{dm}^{3} / \mathrm{h}$ during heating and cooling phases for the 22 tested coal samples

\begin{tabular}{|c|c|c|c|c|c|c|c|}
\hline Temperature $\left({ }^{\circ} \mathrm{C}\right)$ & Ethane & Ethylene & Propane & Propylene & Acetylene & Carbon monoxide & Hydrogen \\
\hline \multicolumn{8}{|l|}{ Heating phase } \\
\hline \multicolumn{8}{|l|}{50} \\
\hline Min & 0.71 & 0.80 & 0.72 & 0.83 & 1.00 & 0.50 & 0.50 \\
\hline Max & 0.99 & 1.00 & 0.99 & 1.00 & 1.00 & 0.85 & 1.00 \\
\hline \multicolumn{8}{|l|}{150} \\
\hline Min & 0.72 & 0.77 & 0.74 & 0.80 & 0.75 & 0.55 & 0.56 \\
\hline Max & 0.92 & 0.97 & 0.97 & 0.97 & 0.96 & 0.81 & 0.82 \\
\hline \multicolumn{8}{|l|}{250} \\
\hline Min & 0.68 & 0.68 & 0.74 & 0.77 & 0.58 & 0.68 & 0.60 \\
\hline Max & 0.88 & 0.98 & 0.95 & 0.97 & 0.94 & 0.88 & 0.90 \\
\hline \multicolumn{8}{|l|}{ Cooling phase } \\
\hline \multicolumn{8}{|l|}{250} \\
\hline Min & 0.56 & 0.39 & 0.60 & 0.43 & 0.34 & 0.16 & 0.13 \\
\hline Max & 0.71 & 0.62 & 0.77 & 0.85 & 0.75 & 0.50 & 0.34 \\
\hline \multicolumn{8}{|l|}{150} \\
\hline Min & 0.59 & 0.49 & 0.62 & 0.64 & 0.50 & 0.26 & 0.42 \\
\hline Max & 0.77 & 0.77 & 0.83 & 0.88 & 0.90 & 0.54 & 1.00 \\
\hline \multicolumn{8}{|l|}{50} \\
\hline Min & 0.63 & 0.60 & 0.68 & 0.80 & 0.53 & 0.44 & 1.00 \\
\hline Max & 0.84 & 0.88 & 0.88 & 0.93 & 1.00 & 0.82 & 1.00 \\
\hline \multicolumn{8}{|l|}{30} \\
\hline Min & 0.71 & 0.63 & 0.76 & 0.83 & 0.83 & 0.43 & 1.00 \\
\hline Max & 0.98 & 0.95 & 0.99 & 1.00 & 1.00 & 0.86 & 1.00 \\
\hline
\end{tabular}



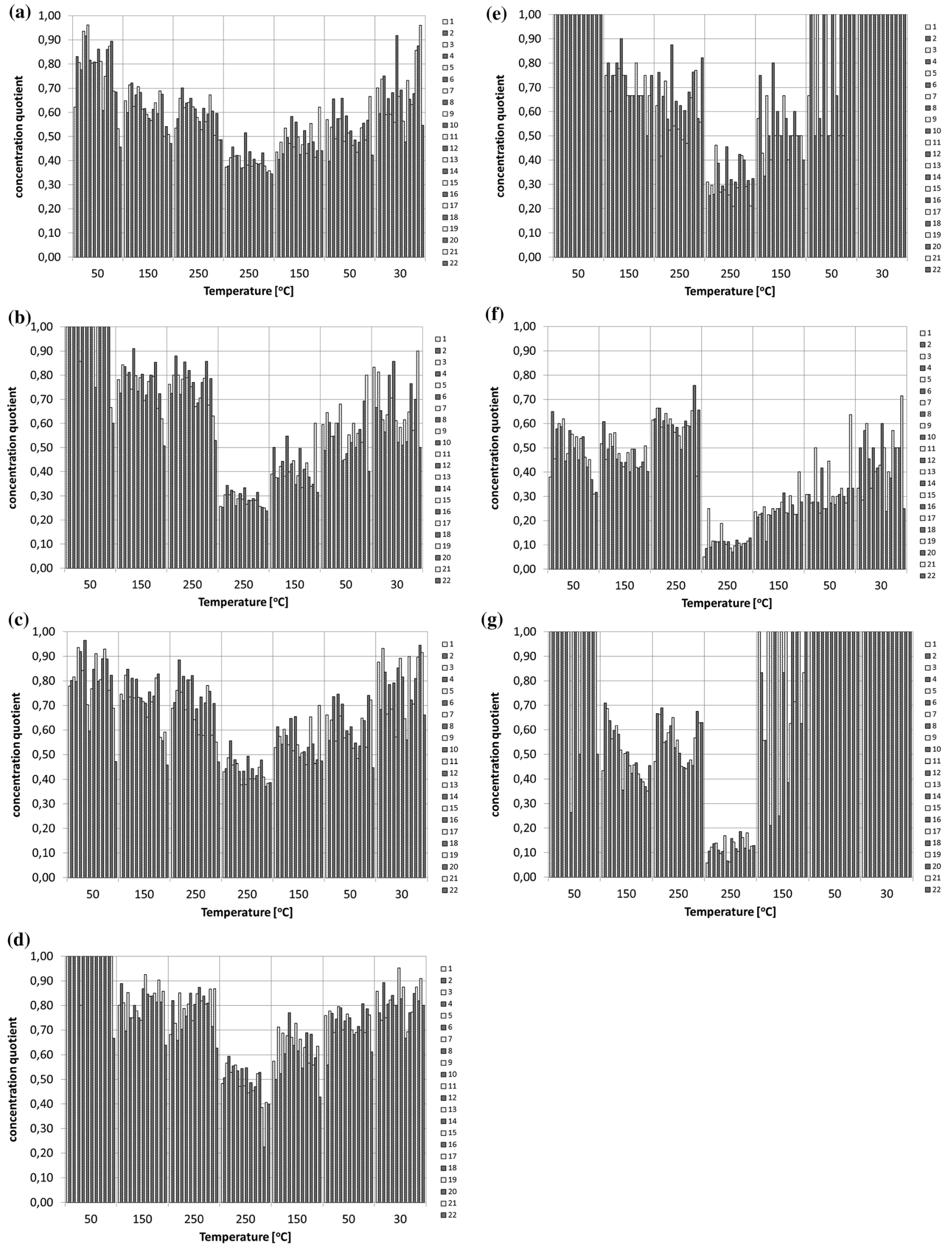
4Fig. 6 Changes in the proportions between the concentrations of gases flowing from the reactor at the flow rate of synthetic air and nitrogen of $12 \mathrm{dm}^{3} / \mathrm{h}$ and the concentrations obtained at the flow rate of $4 \mathrm{dm}^{3} / \mathrm{h}$ for heating and cooling phases: a ethane, $\mathbf{b}$ ethylene, c propane, $\mathbf{d}$ propylene, e acetylene, $\mathbf{f}$ carbon monoxide, $\mathbf{g}$ hydrogen

\section{Conclusions}

(1) The analysis of the changes in the proportions of the concentration of gases flowing from the reactor obtained at the synthetic air and nitrogen flow rates of $8 \mathrm{dm}^{3} / \mathrm{h}$ and $4 \mathrm{dm}^{3} / \mathrm{h}$ as well as $12 \mathrm{dm}^{3} / \mathrm{h}$ and $4 \mathrm{dm}^{3} / \mathrm{h}$ demonstrated that during the heating phase the proportions decreased with the temperature increase for ethane, ethylene, propane, propylene and acetylene. The proportions of the concentrations determined for carbon monoxide increased in both variants.
(2) In the cooling phase, all the analyzed proportions of gas concentrations systematically increased. Very low values of gas concentrations at the temperature of 50 and $30^{\circ} \mathrm{C}$-close to the Lower Limit of Quantification-caused an increase of some of the proportions to the value of 1 .

(3) The determined values of $\mathrm{CO} / \mathrm{CO}_{2}$ index increase with the increase in temperature for all the 22 coal samples in every variant of flow rate $-8 \mathrm{dm}^{3} / \mathrm{h}$ and $4 \mathrm{dm}^{3} / \mathrm{h}$ as well as $12 \mathrm{dm}^{3} / \mathrm{h}$ and $4 \mathrm{dm}^{3} / \mathrm{h}$. The values decrease with the decrease in temperature. It was also observed that the change of the flow rate has an impact on the value of the index.

(4) In the underground mining conditions, combating fire hazards requires restricting the inflow of air to the heated zone. So far the analysis of changes in gas concentrations and the calculations of fire indices assumed that the proportions between the gases

Table 5 Minimum and maximum values of gas concentration quotients determined for the synthetic air and nitrogen flow rates of $12 \mathrm{dm}^{3} / \mathrm{h}$ and $4 \mathrm{dm}^{3} / \mathrm{h}$ during heating and cooling phases for the tested 22 coal samples

\begin{tabular}{|c|c|c|c|c|c|c|c|}
\hline Temperature $\left({ }^{\circ} \mathrm{C}\right)$ & Ethane & Ethylene & Propane & Propylene & Acetylene & Carbon monoxide & Hydrogen \\
\hline \multicolumn{8}{|l|}{ Heating phase } \\
\hline \multicolumn{8}{|l|}{50} \\
\hline Min & 0.46 & 0.60 & 0.47 & 0.67 & 1.00 & 0.31 & 0.26 \\
\hline Max & 0.96 & 1.00 & 0.96 & 1.00 & 1.00 & 0.65 & 1.00 \\
\hline \multicolumn{8}{|l|}{150} \\
\hline Min & 0.47 & 0.51 & 0.46 & 0.64 & 0.50 & 0.40 & 0.35 \\
\hline Max & 0.72 & 0.91 & 0.85 & 0.93 & 0.90 & 0.61 & 0.71 \\
\hline \multicolumn{8}{|l|}{250} \\
\hline Min & 0.49 & 0.53 & 0.47 & 0.63 & 0.41 & 0.38 & 0.44 \\
\hline Max & 0.70 & 0.88 & 0.88 & 0.87 & 0.88 & 0.76 & 0.69 \\
\hline \multicolumn{8}{|l|}{ Cooling phase } \\
\hline \multicolumn{8}{|l|}{250} \\
\hline Min & 0.35 & 0.24 & 0.37 & 0.22 & 0.21 & 0.05 & 0.06 \\
\hline $\operatorname{Max}$ & 0.52 & 0.34 & 0.56 & 0.59 & 0.46 & 0.25 & 0.18 \\
\hline \multicolumn{8}{|l|}{150} \\
\hline Min & 0.40 & 0.31 & 0.46 & 0.43 & 0.33 & 0.11 & 0.21 \\
\hline Max & 0.62 & 0.60 & 0.70 & 0.77 & 0.80 & 0.40 & 1.00 \\
\hline \multicolumn{8}{|l|}{50} \\
\hline Min & 0.40 & 0.40 & 0.45 & 0.56 & 0.50 & 0.23 & 1.00 \\
\hline Max & 0.67 & 0.80 & 0.75 & 0.81 & 1.00 & 0.64 & 1.00 \\
\hline \multicolumn{8}{|l|}{30} \\
\hline Min & 0.48 & 0.50 & 0.56 & 0.67 & 1.00 & 0.24 & 1.00 \\
\hline Max & 0.96 & 0.90 & 0.94 & 0.95 & 1.00 & 0.71 & 1.00 \\
\hline
\end{tabular}



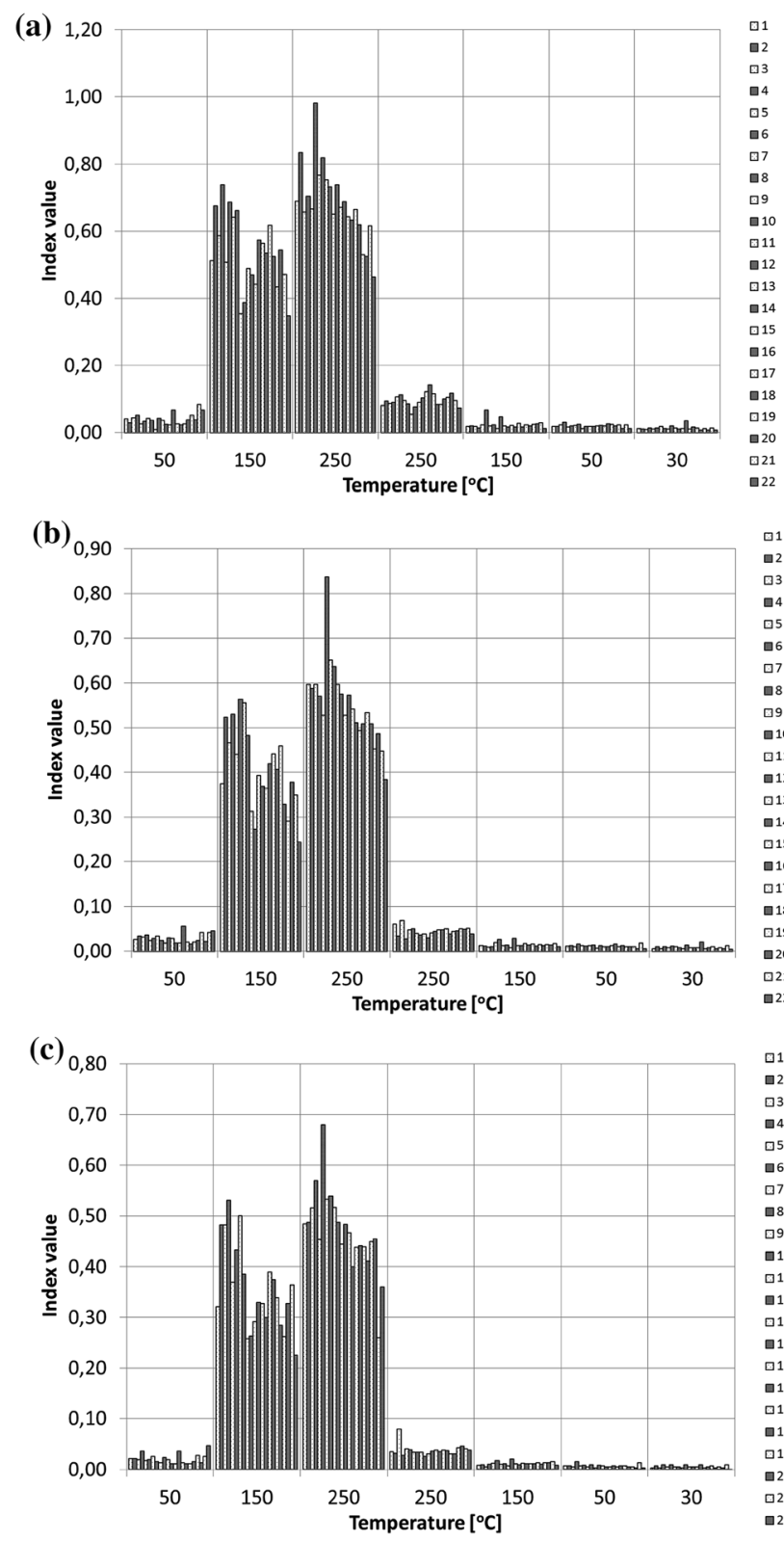

Fig. 7 Changes in the $\mathrm{CO} / \mathrm{CO}_{2}$ index for the heating and cooling phases at the synthetic air and nitrogen flow rate of: a $4 \mathrm{dm}^{3} / \mathrm{h}$, b $8 \mathrm{dm}^{3} / \mathrm{h}$, c $12 \mathrm{dm}^{3} / \mathrm{h}$

depend on temperature. For the purpose of assessing fire hazard, other criteria of the cooling and heating phase must be adopted; in addition, the impact of the changing volume of air inflow must be taken into consideration. Therefore, in order to precisely determine the temperature for each coal, a modeling research must be conducted and appropriate indices which take into account the impact of flow rates should be selected.
Table 6 Minimum and maximum values of $\mathrm{CO} / \mathrm{CO}_{2}$ index determined at the synthetic air and nitrogen flow rate of: a) $4 \mathrm{dm}^{3} / \mathrm{h}$, b) $8 \mathrm{dm}^{3} / \mathrm{h}$, c) $12 \mathrm{dm}^{3} / \mathrm{h}$ for the 22 tested coal samples

\begin{tabular}{llll}
\hline Temperature & $\mathrm{CO} / \mathrm{CO}_{2}$ at & $\mathrm{CO} / \mathrm{CO}_{2}$ at & $\mathrm{CO} / \mathrm{CO}_{2}$ at \\
$\left({ }^{\circ} \mathrm{C}\right)$ & $4 \mathrm{dm}^{3} / \mathrm{h}$ flow & $8 \mathrm{dm}^{3} / \mathrm{h}$ flow & $12 \mathrm{dm}^{3} / \mathrm{h}$ flow \\
& rate & rate & rate \\
\hline
\end{tabular}

Heating phase

50

$\begin{array}{cccc}\text { Min } & 0.01 & 0.02 & 0.02 \\ \text { Max } & 0.08 & 0.06 & 0.045 \\ 150 & & & \\ \text { Min } & 0.35 & 0.24 & 0.23 \\ \text { Max } & 0.74 & 0.56 & 0.53 \\ 250 & & & \\ \text { Min } & 0.46 & 0.38 & 0.26 \\ \text { Max } & 0.98 & 0.84 & 0.68\end{array}$

Cooling phase

250

$\begin{array}{clll}\text { Min } & 0.05 & 0.03 & 0.03 \\ \text { Max } & 0.14 & 0.078 & 0.08 \\ 150 & & & \\ \text { Min } & 0.01 & 0.01 & 0.01 \\ \text { Max } & 0.067 & 0.03 & 0.02 \\ 50 & & & \\ \text { Min } & 0.01 & 0.01 & 0.00 \\ \text { Max } & 0.03 & 0.02 & 0.02 \\ 30 & & 0.00 & 0.00 \\ \text { Min } & 0.01 & 0.02 & 0.01 \\ \text { Max } & 0.04 & \end{array}$

Acknowledgements This work was supported by the Ministry of Science and Higher Education, Poland (No. 14303018).

\section{Compliance with ethical standards}

Conflict interest None of the authors have any competing interests in the manuscript.

Open Access This article is distributed under the terms of the Creative Commons Attribution 4.0 International License (http://crea tivecommons.org/licenses/by/4.0/), which permits unrestricted use, distribution, and reproduction in any medium, provided you give appropriate credit to the original author(s) and the source, provide a link to the Creative Commons license, and indicate if changes were made. 


\section{References}

Adamus A, Sancer J, Guranova P, Zubicek V (2011) An investigation of the factors associated with interpretation of mine atmosphere for spontaneous combustion in coal mines. Fuel Process Technol 92:663-670

Arisoy A, Beamish B (2015) Mutual effects of pyrite and moisture on coal self-heating rates and reaction rate data for pyrite oxidation. Fuel 139:107-114

Beamish BB (2005) Comparison of the $R 70$ self-heating rate of New Zealand and Australian coals to Suggate rank parameter. Int $\mathrm{J}$ Coal Geol 64:139-144

Beamish BB, Arisoy A (2008) Effect of mineral matter on coal selfheating rate. Fuel $87: 125-130$

Beamish BB, Barakat MA, George JD (2001) Spontaneous-combustion propensity of New Zealand coals under adiabatic conditions. Int J Coal Geol 45:217-224

Brady D, Harrison P, Bell S (2009) The need for a tube bundle system for an effective mine gas monitoring system. In: Proceedings of the 9th international ventilation congress. New Delhi, India, 2009, pp 907-916

Bystroń H (1997) Stan Pożaru, zapalenie i wybuch gazów podczas aktywnego i pasywnego gaszenia [Fire, ignition and gas explosion during active and passive extinguishing]. Arch Min Sci 42

Charriere D, Pokryszka Z, Beha P (2010) Effect of pressure and temperature on diffusion of $\mathrm{CO}_{2}$ and $\mathrm{CH}_{4}$ into coal from the Lorraine basin (France). Int J Coal Geol 81(4):373-380

Dai GL (2007) Study on the gaseous products in coal oxidation at low temperature. Coal Mine Safety 1:1-4

Davis JD, Bryne JF (1926) Influence of moisture on the spontaneous heating of coal. Ind Eng Chem 18(3):233-236

Deng J, Ma X, Zhang Y, Li Y, Zhu W (2015) Effect of pyrite on the spontaneous combustion of coal. Int $\mathrm{J}$ Coal Sci Technol 2(4):306-311

Dudzińska A, Howaniec N, Smoliński A (2015) Experimental study on sorption and desorption of propylene on polish hard coals. Energ Fuel 29(8):4850-4854

Dudzińska A, Howaniec N, Smoliński A (2017) Effect of coal grain size on sorption capacity with respect to propylene and acetylene. Energies. https://doi.org/10.3390/en10111919

Feng X, Adamus A (2014) Overview of research and use of indicator gases of coal spontaneous combustion in China. GeoScience Engineering 60:55-65

Howaniec N (2016a) Development of porous structure of lignite chars at high pressure and temperature. Fuel Process Technol 154:163-167

Howaniec N (2016b) The effects of pressure on coal chars porous structure development. Fuel 172:118-123

Hu X, Yang S, Zhou X, Yu Z, Hu C (2015) Coal spontaneous combustion prediction in gob using chaos analysis on gas indicators from upper tunnel. J Nat Gas Sci Eng 26:461-469
Kaji R, Hishinuma Y, Nakamura Y (1985) Low temperature oxidation of coals: effects of pore structure and coal composition. Fuel 64:297-302

Kim AG (2004) Locating fires in abandoned underground coalmines. Int J Coal Geol 9:49-62

Lu P, Liao GX, Li PD (2004) Experimental research on index gas of the coal spontaneous at low temperature stage. J Loss Prevent Proc 17(3):243-247

Lu W, Cao YJ, Tien JC (2017) Method for prevention and control of spontaneous combustion of coal seam and its application in mining field. Int J Min Sci Technol 27(5):839-846

Nugroho YS (2000) Low-temperature oxidation of single and blended coals. Fuel 79:1951-1961

Ren TX, Edwards JS, Clarke D (1999) Adiabatic oxidation study on the propensity of pulverised coals to spontaneous combustion. Fuel 78:1611-1620

Singh AK, Singh RVK, Singh MP, Chandra H, Shukla NK (2007) Mine fire gas indices and their application to Indian underground coal mine fires. Int J Coal Geol 69:192-204

Taraba B, Pavelec Z (2014) Investigation of the spontaneous combustion susceptibility of coal using the pulse flow calorimetric method: 25 years of experience. Fuel 125:101-105

Wang H, Dlugogorski BZ, Kennedy EM (1999) Theoretical analysis of reaction in low-temperature oxidation of coal. Fuel 78:1073-1081

Wang H, Dlugogorski BZ, Kennedy EM (2003) Coal oxidation at low temperatures: oxygen consumption, oxidation products, reaction mechanism and kinetic modelling. Prog Energy Combust Sci 29:487-513

Wojtacha-Rychter K, Howaniec N, Smoliński A (2019) The effect of coal grain size on the sorption of hydrocarbons from gas mixtures. Int J Energ Res. https://doi.org/10.1002/er.4490

Xia T, Zhou F, Liu J, Kang J, Gao F (2014) A fully coupled hydrothermo-mechanical model for the spontaneous combustion of underground coal seams. Fuel 125:106-115

Yuan L, Smith AC (2011) $\mathrm{CO}$ and $\mathrm{CO}_{2}$ emissions from spontaneous heating of coal under different ventilation rates. Int J Coal Geol 88(1):24-30

Zhang J, Kuenzer C (2007) Thermal surface characteristic of coal fires 1 results of in situ measurements. J Appl Geophys 63(3-4):117-134

Zhang Y, Wang J, Wu J, Xue S, Li Z, Chang L (2015) Modes and kinetics of $\mathrm{CO}_{2}$ and $\mathrm{CO}$ production from low-temperature oxidation of coal. Int J Coal Geol 140:1-8

Zubicek V, Adamus A (2013) Susceptibility of coal to spontaneous combustion verified by modified adiabatic method under conditions of Ostrava-Karvina Coalfield, Czech Republic. Fuel Process Technol 113:63-66 